\title{
Megarhizoliths in Pleistocene aeolian deposits from Gran Canaria (Spain): Ichnological and palaeoenvironmental significance
}

\author{
A.M. Alonso-Zarza a,*, J.F. Genise ${ }^{\text {b }}$, M.C. Cabrera ${ }^{\text {c }}$, J. Mangas ${ }^{c}$, A. Martín-Pérez a \\ A. Valdeolmillos ${ }^{a}$, M. Dorado-Valiño ${ }^{d}$ \\ a Dpto Petrología y Geoquímica, Fac. CC. Geológicas, IGE-CSIC, Universidad Complutense de Madrid, 28040 Madrid, Spain \\ b CONICET, Museo Paleontológico Egidio Feruglio, Av. Fontana 140, 9100 Trelew, Chubut, Argentina \\ c Dpto de Física, Universidad de Las Palmas de Gran Canaria, 35017, Las Palmas de Gran Canaria, Spain \\ d Dpto de Geología, Universidad de Alcalá, Edificio de Ciencias, Campus Universitario, 28871. Alcalá de Henares, Madrid, Spain
}

\section{A R T I C L E I N F O}

\section{Article history:}

Received 12 December 2007

Received in revised form 6 March 2008

Accepted 15 April 2008

\section{Keywords:}

Megarhizoliths

Roots

Trace fossils

Aeolian sands

Gran Canaria

Spain

\begin{abstract}
A B S T R A C T
The Pleistocene dune field of Tufia, located on the east of Gran Canaria (Spain), contains different stratigraphic levels of indurated pillar-like structures that are interpreted as megarhizoliths. The megarhizoliths occur at the top of different aeolian sets and reach $31.5 \mathrm{~cm}$ in diameter and over $1 \mathrm{~m}$ in height. These scattered, free-standing, vertical, cylindrical-to-slightly conical columns usually appear as hollow cylinders, displaying elliptical cross-sections aligned with the prevailing wind. On the leeward side of some specimens the external wall shows a tail of rock matrix resembling a sort of "wind shadow". These tails and other remains of the associated rock matrix show a texture composed of long, horizontal, parallel cylinders orientated with the wind.

Internally the most complete structures show five concentrically arranged zones: Zone (a), is a central pore corresponding to the cavity originally occupied by the root; Zones (b) and (c), which include alveolar and laminated carbonate textures indicating that carbonate precipitation was mostly induced by the roots and their associated microorganisms; and Zones (d) and (e), consisting mostly of aeolian sands. In (d) the sand grains show thin micritic coatings whereas in (e) vadose aragonite cements can be seen on the grain surface suggesting a less biogenic influence in their formation. The degree of cementation and the time of the precipitation of carbonate around the roots controlled the preservation of these zones. Thus, in some cases, Zones b, c and/or d are not preserved. Cylinders are up to 30× the diameter of the root that nucleated them. The presence of the megarhizoliths at the top of the aeolianite beds indicates that aeolian sedimentation halted several times, allowing soil formation and plant colonisation during slightly more humid periods. The occurrence of megarhizoliths is further proof of the alternation of arid and slightly more humid climates in the north Atlantic during the last glacial period. It is also noted that they may be misinterpreted as animal trace fossils or tree trunk casts, resulting in incorrect ichnological or palaenenvironmental interpretations.
\end{abstract}

\section{Introduction}

Criteria for distinguishing between fossil root and animal traces have been provided by different authors (Klappa, 1980; Ekdale et al., 1984). An oversimplification still remains when defining both types of traces since root traces do not always show downward bifurcation, tapering along their length, and radiation from a central axis, as classically described. Most analyses of root-calcification products have focused on small root structures just a few centimetres in diameter and a few decimetres in length; a few have described larger calcified root systems (megarhizoliths sensu McNamara, 1995). Megarhizoliths are of particular interest because they may be misinterpreted as animal trace fossils or tree trunk casts. Carbonate megarhizoliths have also been recorded in aeolianites from Australia (McNamara, 1995), but detailed descriptions are lacking. The present work describes carbonate megarhizoliths several decimetres in diameter and over $1 \mathrm{~m}$ in length at Tufia on the island of Gran Canaria (Spain).

Rhizoliths in calcretes and aeolianites are widely discussed in the sedimentological and ichnological literature. The pioneering work of Calvet et al. (1975) described the macro- and micromorphology of Pleistocene rhizocretions from Mallorca (Spain) and laid down the basis for understanding the mechanisms of carbonate precipitation around and within roots. Based on this, Klappa (1980) established the importance of studying rhizoliths and proposed criteria for their classification and distinction from burrows. The mechanisms of their genesis and formation were also well discussed. Other papers have focused on the process of their formation, and their significance for environmental studies (Mount and Cohen, 1984; Loope, 1988; Jones and Kwok-Choi, 1988; McLaren, 1995; Murray et al., 2004). In soils of 
arid to semiarid climates, rhizoliths have also been recognised by their calcified root cells and/or Microcodium (Klappa, 1978; Kosir, 2004). Root traces are indicators of subaerial exposure surfaces, and their distribution and morphology have been used to decipher palaeoclimatic conditions (Retallack, 2001).

The objectives of the present work are to: (1) describe and interpret the macro- and micromorphological features of the free-standing columnar structures within aeolian deposits at Tufia; (2) analyse the main processes (pedogenesis/diagenesis/weathering) involved in their formation and preservation; (3) compare them with similar structures and propose additional criteria to distinguish between rhizoliths and animal traces; (4) stress the ichnological importance of these structures; and (5) discuss their interest in the interpretation of ancient palaeoenvironments, focusing on the palaeoclimate and vegetation responsible for their formation.

\section{Geographical and geological setting}

The Pleistocene to Holocene aeolian deposits of Tufia on the eastern coast of Gran Canaria are located within the municipal area of Telde, between Morrete de Tufia to the north and the Ojos de Garza Gully to the south (Fig. 1). These lightly consolidated or loose, sandy deposits form an outcrop (lying in a NNE-SSW direction) about $1500 \mathrm{~m}$ in length, $300 \mathrm{~m}$ in width, and $9 \mathrm{~m}$ thick. The dune field covers volcanic materials belonging to the Post-Roque Nublo magmatic phasethe youngest volcanic products to be found on Gran Canaria (ITGE, 1990; Guillou et al., 2004). These alkaline-undersaturated lavas and pyroclastites erupted from the NW-SE rift and from local emission centres
(Carracedo et al., 2002). The K-Ar ages reported by Guillou et al. (2004) for the lava flows below the dune field range from 1.60 to 2.93 Ma.

The Tufia dune field is formed by Upper Pleistocene to Holocene dunes (ITGE, 1990; Carracedo et al., 2002) that are presently being remobilised by aeolian erosion. ITGE (1990) proposed that the area experienced the alternation of humid and dry episodes based upon the superposition of aeolian sands by thin calcrete beds, continental gastropods (Hemicycla sp. and Trochoidea desperauxi), and plant remains. The present landscape does not preserve the original morphology of the dunes due to strong human impact. Abandoned sand quarries provided good outcrops and sampling sites for this study (Fig. 2).

The present vegetation in the area belongs to the Euphorbio paraliasi-Cyperetum kalil association (CMA, 2005). These plants have to withstand extreme conditions, including very strong sunshine, strong winds and the influence of the sea. In addition, the climate of Tufia has desert-like characteristics; there is a strong water deficit (the mean annual precipitation is $118.5 \mathrm{~mm}$ ), the mean annual temperature is $20.5^{\circ} \mathrm{C}$, the mean minimum temperature is $17.4^{\circ} \mathrm{C}$ (in January), and the mean maximum temperature is $23.6{ }^{\circ} \mathrm{C}$ (in August) (Camino, 1997). The north-easterly trade winds are an important feature of the climate of the eastern part of Gran Canaria. Although they are very common all year, their intensity increases during summer when they have a mean speed of $40 \mathrm{~km} / \mathrm{h}$; they sometimes reach $70 \mathrm{~km} / \mathrm{h}$. The wind is responsible for the transport of sand inland-the reason for the existence of other $\mathrm{N}-\mathrm{S}$-aligned dune fields on the island (such as those of Las Palmas de Gran Canaria, Arinaga, Maspalomas).

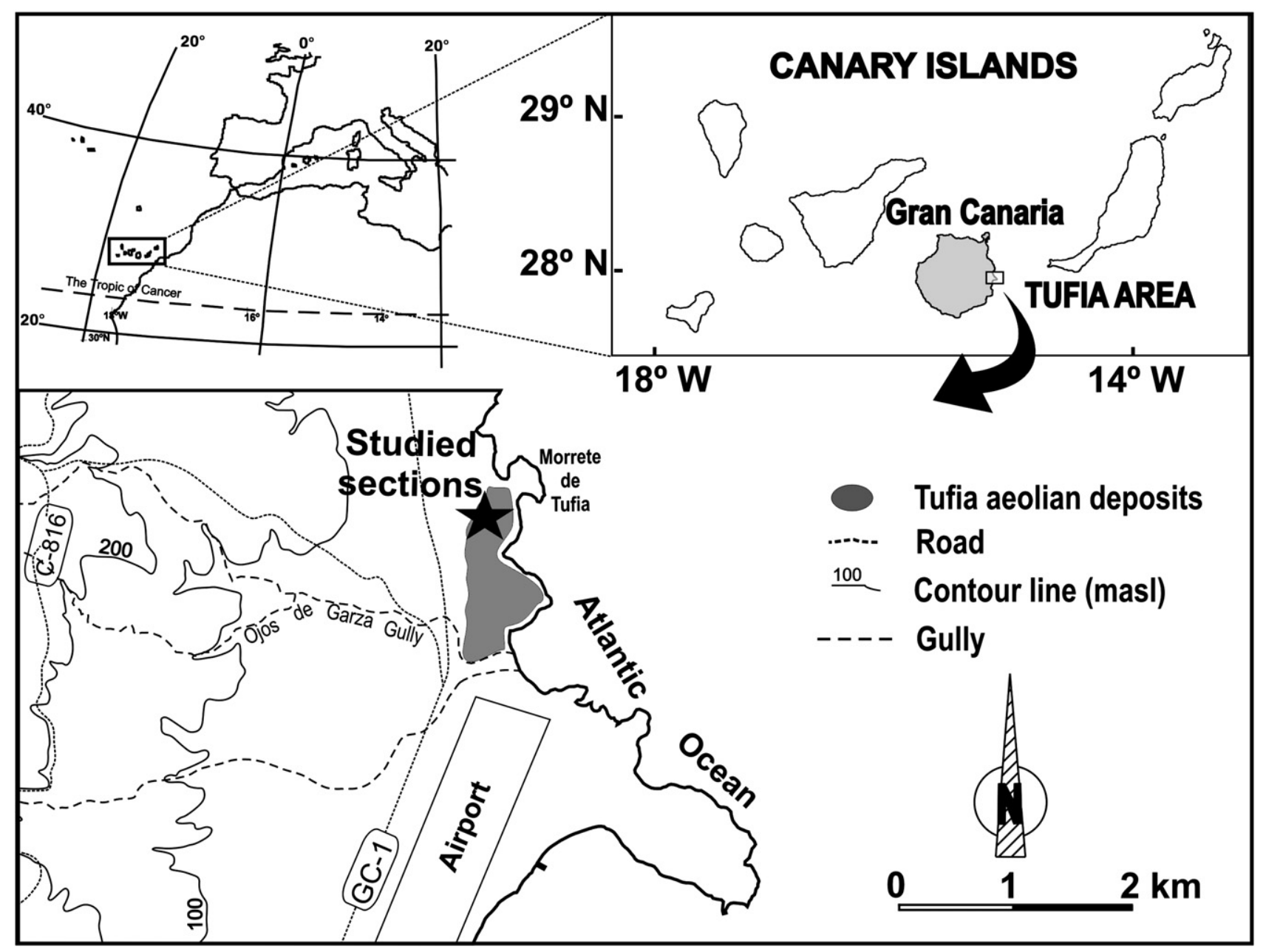

Fig. 1. Location of the Tufia aeolian deposits on Gran Canaria, with indications of the topography of the area. 

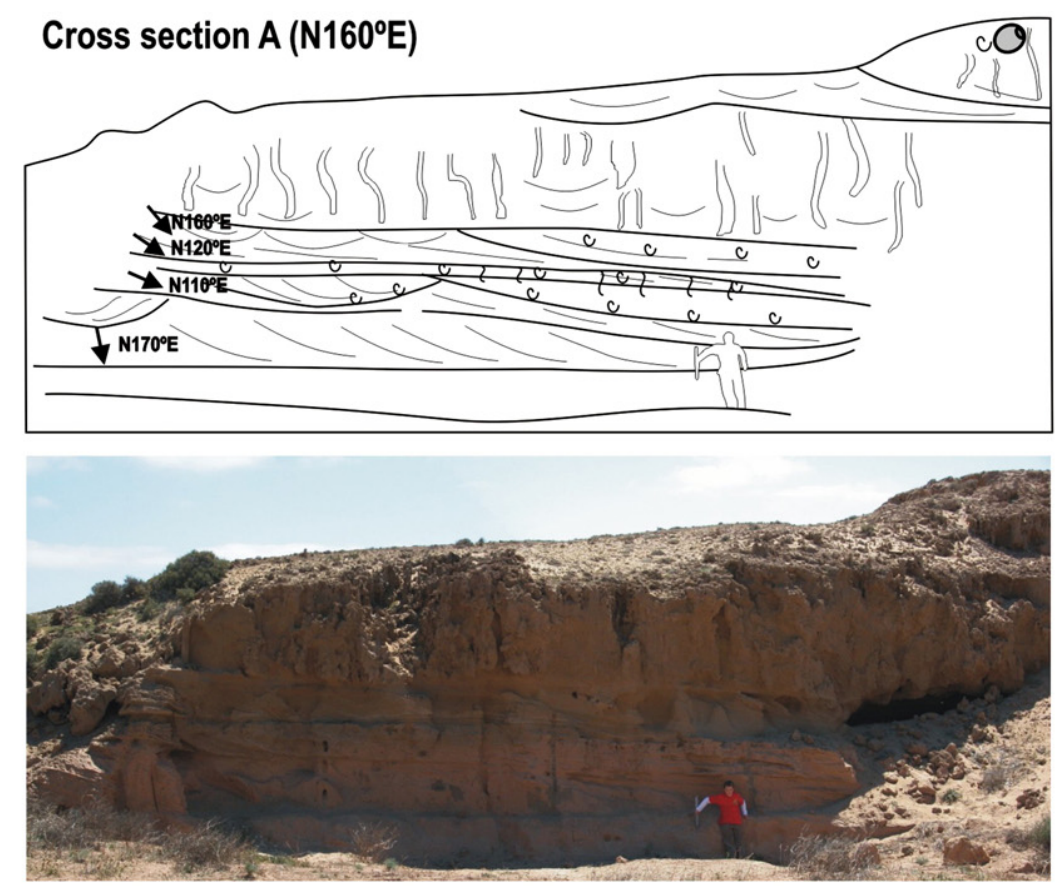

\section{Cross section $B\left(\mathrm{~N} 150^{\circ} \mathrm{E}\right)$}
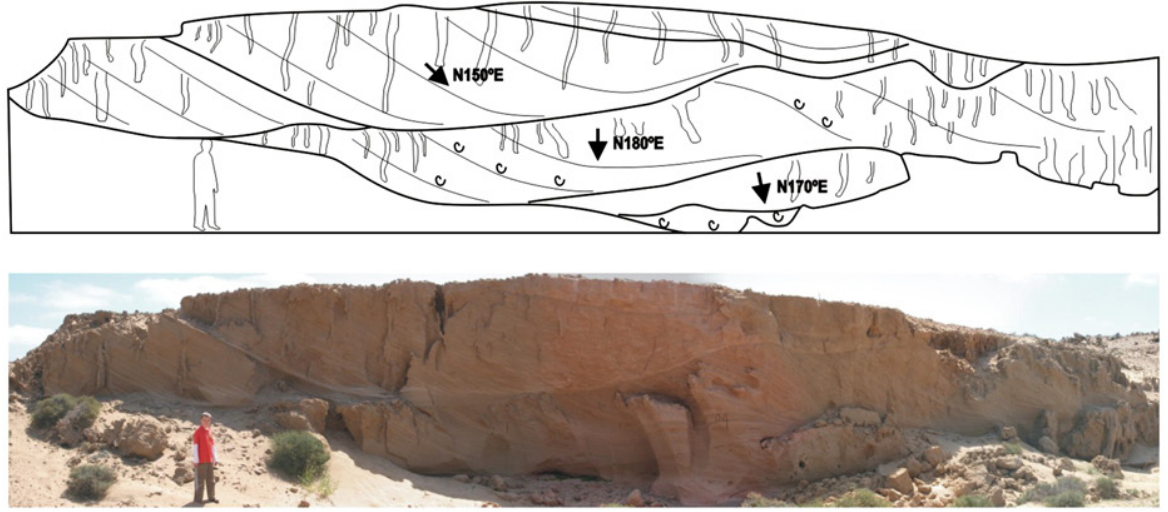

\section{LEGEND}

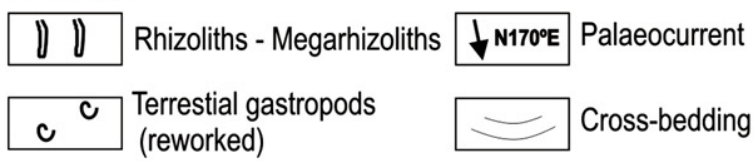

Fig. 2. Abandoned quarries in the Tufia area. Two cross-sections (A and B) were studied. The main sedimentological features of each section are sketched below each picture. For scale see the person (Marcos) in the photograph (height $1.55 \mathrm{~m}$ ).

\subsection{Sedimentology and petrology of the aeolianites}

The dune system was studied by examining two cross-sections (Fig. 2A and B). The total thickness of the aeolian deposits at Tufia is $8.65 \mathrm{~m}$. The sand contains large-scale cross-bed sets up to $1.7 \mathrm{~m}$ thick, with erosive bases. Sometimes the cross-strata wedge upwards from the base of the sets, showing typical aeolian sedimentary structures with dunes and foresets climbing over earlier dunes. The upper part of these sets contains the pillar-like structures (Fig. 2). In some dunes, broken terrestrial gastropods were identified at the base of the sets. They occur as thin lag deposits that were remobilised from deposits formed during less arid periods. The palaeocurrent measurements show a wide dispersion from $\mathrm{N} 110^{\circ} \mathrm{E}$ to $\mathrm{N} 180^{\circ} \mathrm{E}$, similar to the present wind regime. The upper part of the cross-sections shows a proliferation of pillars; these are very prominent because of the denuding of loose sand by current aeolian activity (Fig. 3A and B). Palaeosol fea- tures are very scarce throughout the section, and are limited to the presence of root structures that destroy stratification. These palaeosols are classified as Entisols (Retallack, 2001) because they lack other soil features and show very little alteration of the parent material, which is mostly the result of root activity. The Entisols bearing the Tufia pillars also shows dense boxworks of small rhizoliths (Fig. 3C). The top of the outcrop consists of a fine sand-silt layer with small rhizoliths, large gastropod shells and insect trace fossils (Rebuffoichnus isp) (Fig. 3D). Presently, living Cyperaceae (Cyperus capitatus, Vandelle) growing in loose sand close to the pillars show slanting roots of small size with concretions ( $4 \mathrm{~mm}$ in diameter) around them.

\subsection{Grain size and composition of the aeolianites}

The sands of the Tufia dunes are fine- to medium-grained (between 0.181 and $0.348 \mathrm{~mm}, \sigma=0.052$ ), and, according to Folk and Ward (1957) 

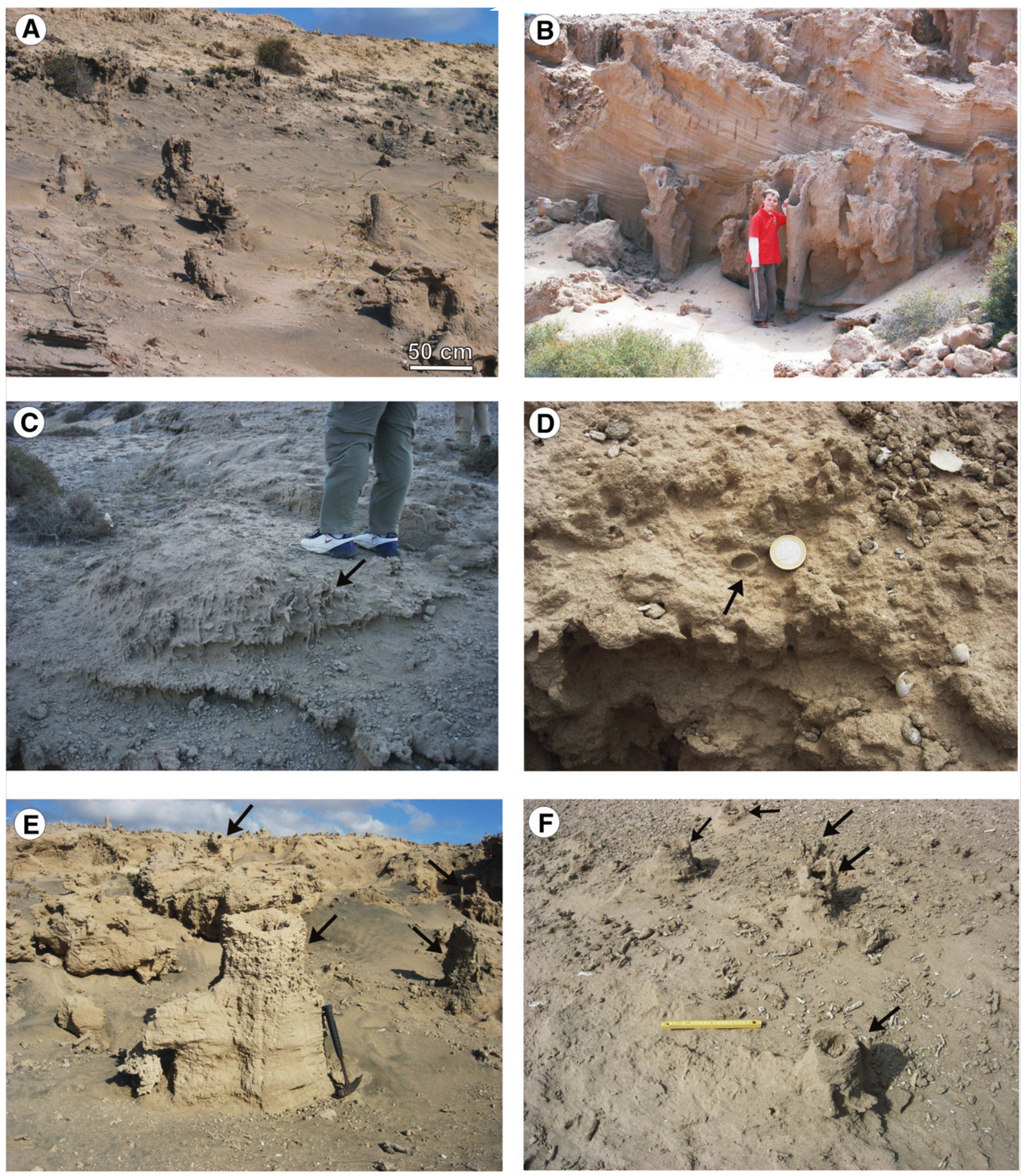

Fig. 3. A. General appearance and distribution of the megarhizoliths in the outcrop. B. The largest specimen observed in the rock matrix, it is about $1.6 \mathrm{~m}$ in height (see Marcos for scale). C. Palaeosol showing a dense boxwork of rhizoliths. D. Uppermost palaeosol showing trace fossils of the insect Rebuffoichnus isp. (arrow). Coin: 2.3 cm. E. Megarhizoliths (arrows) as free-standing columns and included in the rock matrix. Note the tail shown by the specimen at the front. F. Dense distribution of megarhizoliths (arrows) (scale is $20 \mathrm{~cm}$ ).

criteria, vary from well to moderately sorted with extreme sorting values of between 0.429 and $0.807(\sigma=0.134)$. The distribution of the grain sizes has a null or negative asymmetry. The sandy layers with trace fossils have mean grain sizes between the extreme values shown above, with no significant differences compared to the layers without ichnofossils.

The composition of the aeolianites was studied by examining resinimpregnated thin sections, counting 500 point per section. The studied samples show more terrigenous material (less than $75 \%, 50 \%$ on average) than bioclasts (less than $60 \%, 50 \%$ on average). Basic and felsic volcanic rock fragments are the most abundant with proportions of $40.4 \%$ and
$30.9 \%(\sigma=3.6)$. The proportions of volcanic glasses and microcrystalline groundmass range from 9.6 to $22 \%(\sigma=4.2)$. Fragments of sedimentary rocks appear in proportions of $3-12.6 \%(\sigma=3.8)$. The proportion of monomineral grains varies between $8 \%$ and $34.9 \%(\sigma=10)$; most of these are feldspars, clinopyroxenes, opaques and olivines. Amphiboles appear in smaller proportions; feldspathoids and zeolites are rare. Among the bioclasts, red coralline algae (rodolites) and mollusc fragments are the most abundant; foraminifers, echinoderms and bryozoans appear in smaller proportions. The bioclastic and terrigenous components are similar to those found in the Maspalomas dune field (dunes and 
aeolianites) in the south of Gran Canaria (Hernández and Mangas, 2004). The sand grains of the Tufia aeolianites show thin coats of carbonate cement as those described by Gardner and McLaren (1993), Kindler and Hearty (1995) and Mangas et al. (2007).

No important compositional differences can be seen between the layers with or without columns. Thus, the petrographical and mineralogical characteristics of the sand layers are not fundamental for column formation. The larger amounts of non-carbonate compared to carbonate grains suggests that the Tufia aeolianites were formed by important contributions of terrigenous material formed by the erosion
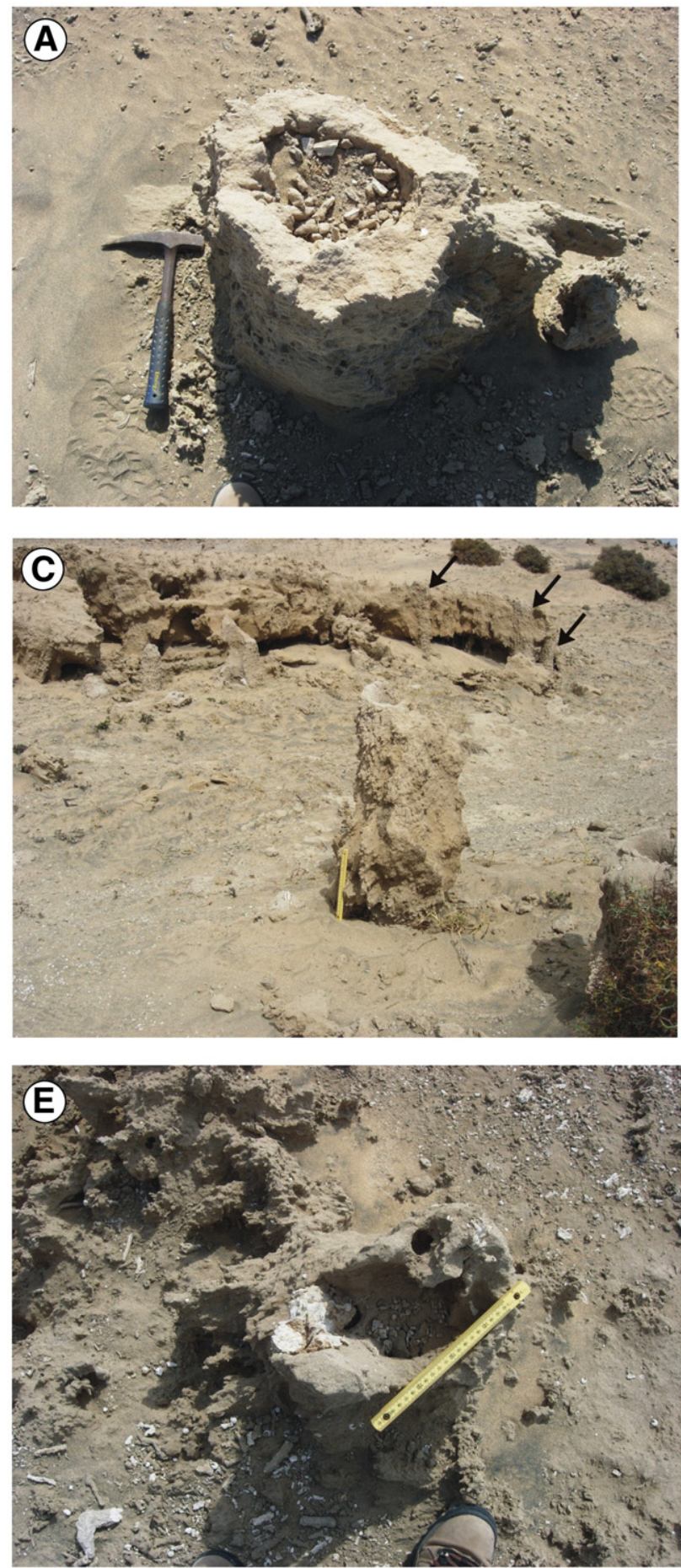

of coastal materials and/or transported through the gullies located to the north of the Tufia area.

\section{Description of the Tufia columnar structures}

\subsection{Macromorphology}

Most of the analysed structures appear as free-standing, vertical, cylindrical (Figs. 3A, E, F and 4A, B and C) to slightly conical (Fig. 4 D) columns scattered in patches over an area of about $5000 \mathrm{~m}^{2}$. A few
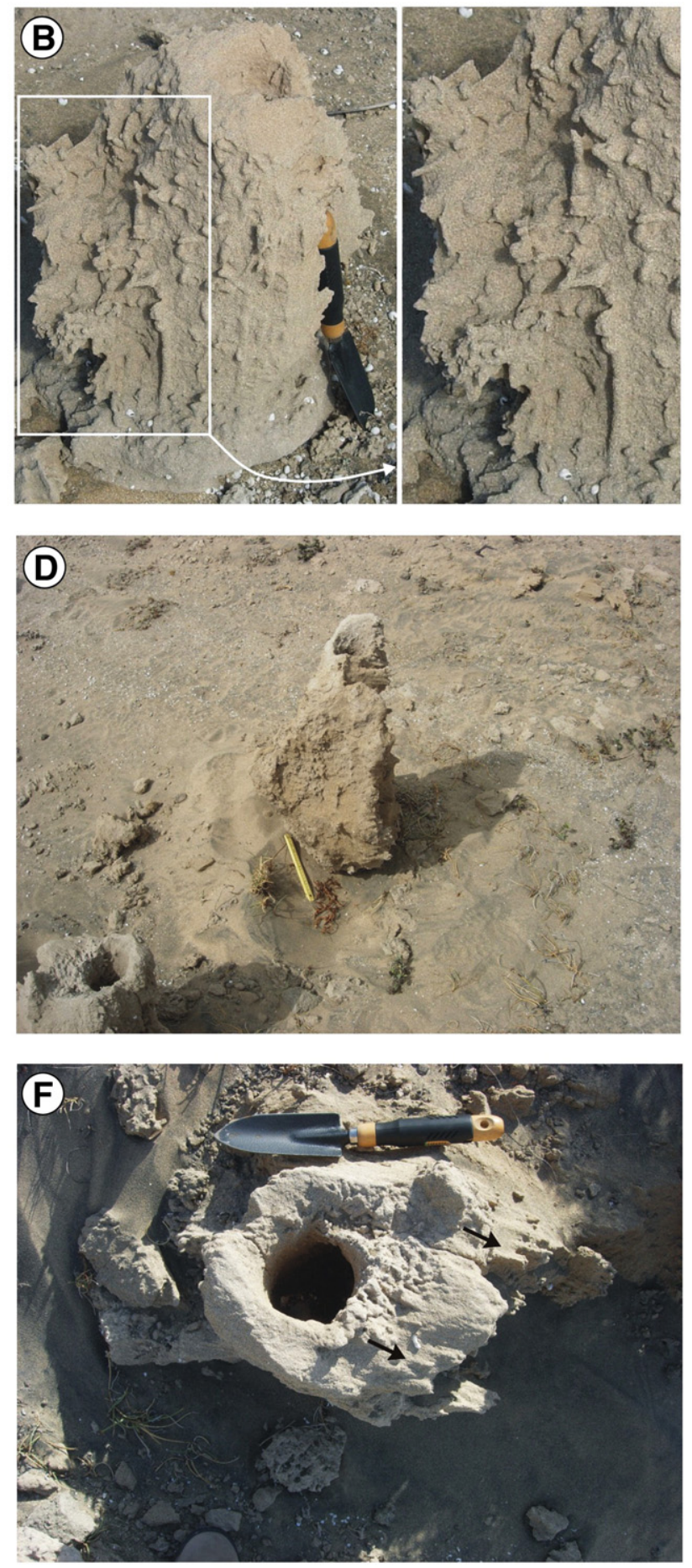

Fig. 4. A. Cross-section showing an eccentric hollow filled with sand. B. Megarhizolith and its tail (see the detailed view) showing an external network of cylindrical structures. C. Free-standing megarhizolith (front) and other specimens included in the upper part of the sand sets (arrows) (scale is $20 \mathrm{~cm}$ ). D. Conical megarhizolith. E. Cross-section showing three cores (original roots): a central cavity with passive fillings, a hollow cylinder (right, up), and a white tube (left). F. Cross-section showing the eccentric hollow and parallel, windorientated cylinders in the tail (the wind comes from the upper left in this picture). 
appear in vertical sections included in the upper part of the sand sets (Figs. 3B and 4C). The lower parts are only occasionally visible in the vertical sections, and the upper parts are always truncated. The distribution alternates between patches of relatively high density in which the columns are separated by less than $2 \mathrm{~m}$, and others almost devoid of them. The densest area had seven specimens in a rectangle of $8.75 \mathrm{~m} \times 2 \mathrm{~m}$. The exposed samples usually appear as hollow cylinders, elliptical in cross-section (Figs. 3E and 4A, E and F), $20 \mathrm{~cm}$ to
$75 \mathrm{~cm}$ in height (mean of the examined samples: $38.9 \mathrm{~cm}, N=17$ ), $4 \mathrm{~cm}$ to $25 \mathrm{~cm}$ in with (mean: $16.8 \mathrm{~cm}, N=18$ ), and $4 \mathrm{~cm}$ to $31.5 \mathrm{~cm}$ in length (mean: $19.1 \mathrm{~cm}, N=17$ ). The long axis of the elliptical section always appears orientated with the prevailing NE-SW wind.

Different macromorphologies were observed in the megarhizoliths exposed as vertical columns in the field: (a) hollow cylinders with a cavity is from $1.5 \mathrm{~cm}$ to $15 \mathrm{~cm}$ (mean: $8.3 \mathrm{~cm}, N=16$ ), in some cases eccentrical, and only part of the most external wall preserved; (b) with
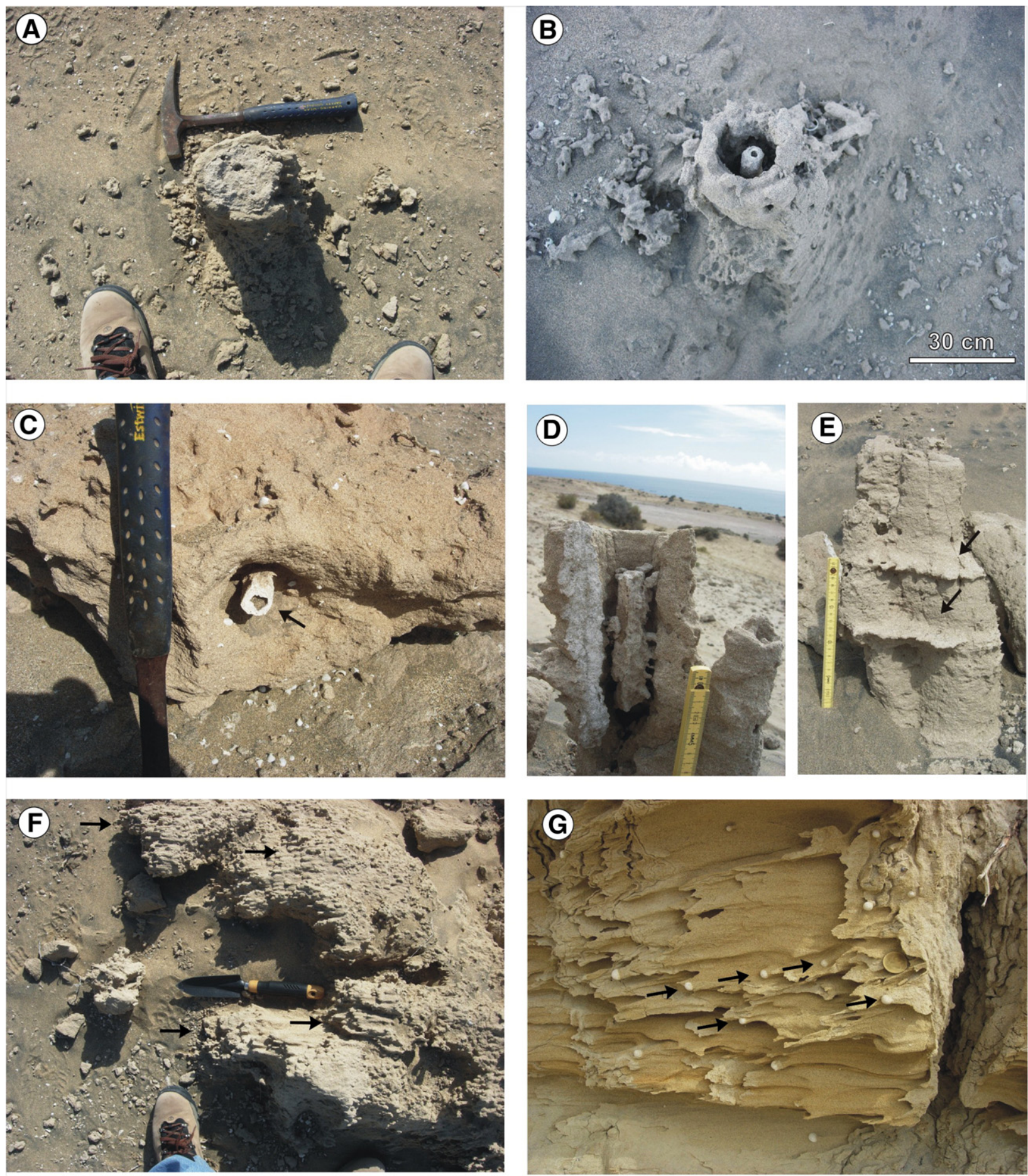

Fig. 5. A. Cross-section showing a central cavity occupied by white carbonate. B. Cross-section showing the central pore, a white tube, a peripheral weathered ring, and a cemented external wall. C. Tube of white carbonate (original root) protruding through the lateral wall of the megarhizolith. D. Longitudinal section of a megarhizolith showing tubes (secondary roots) radiating from the central tube (central root). Note the smaller, lateral rhizolith. E. Lateral view of the megarhizolith in D, showing two rings of remaining rock matrix. F. Remains of palaeosol showing a wind-influenced texture composed of horizontal, parallel cylinders (arrows). G. Palaeodune from the Miocene Pinturas Formation (Argentina) showing wind shadows produced in spherical concretions. Coin: $2.3 \mathrm{~cm}$ 
more than one cavity containing micrite tubes; (c) with no cavity at all (Fig. 5A); or (d) with a cavity having a single central tube (Fig. 5B). Some specimens show lateral tubes that cut across the wall of the structure (Fig. 5C). In other cases, more than one cavity or micrite tube is included in the same structure (Fig. 4E). The most complex specimen observed shows a central cavity including a micrite tube with radiating ones that crossed the surrounding cavity and penetrated the external wall, a second smaller specimen connected laterally (Fig. 5D), and two rings of remaining indurated rock matrix (Fig. 5E).

In some of the non-buried specimens, the external wall shows a rock matrix tail resembling a sort of leeward "wind shadow" (Figs. 3E and $4 \mathrm{~B}, \mathrm{~F}$ ). The tails and the other rock matrix remains associated with them also show a texture composed of long horizontal, parallel, cylinders orientated with the wind (Figs. 4F and 5F). The tails have a triangular or tabular appearance, may be single or double, massive or composed mainly of a network of cylindrical structures (Fig. 4B), and can be longer than the diameter of the whole structure (Fig. 3E). Specimens that are buried in the sand are circular in cross-sections and do not show "wind shadows".

\subsection{Micromorphology}

In cross-section the most complete samples show two different parts that can be separated into five micromorphological zones
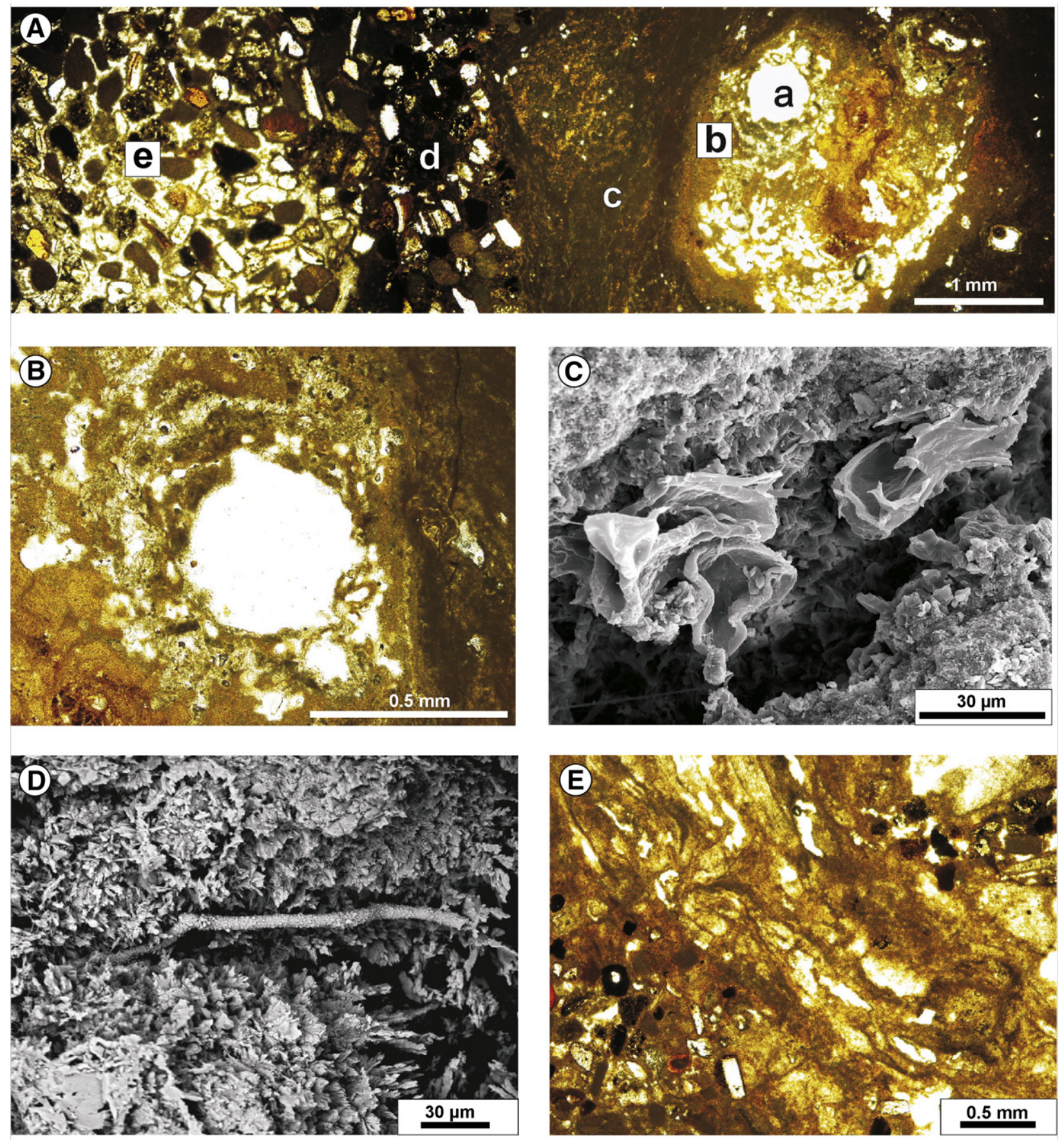

Fig. 6. A. Photomicrograph showing a cross-section of a rhizolith showing the five zones; a, central pore; b, micrite with alveolar structure; $c$, laminated micrite; d, sand grains with micrite coatings; e, sand grains with vadose aragonite cements and thin micrite coatings. B. Detailed view of Zones (a+b), showing the central hole and the alveolar septal micrite. C. SEM image of Zone (b) showing some root organic remains and a high porosity. D. SEM image of Zone (b) in which calcified tubes can be recognised. E. Laminated micrite of Zone (c) composed of alveolar septal structures. 
(Fig. 6A). From the interior to the exterior the following can be seen: (1) a small (1-2 mm) and usually empty core (Zone a) followed by a tube $(0.6-2 \mathrm{~cm})$ of white carbonate (absent in some cases) (Zones b and c), and (2) an external wall ranging formed from cemented sands (Zones $\mathrm{d}$ and e). The external wall shows an outer surface texture composed of short cylindrical structures resembling tunnels. These radiate in all directions, even vertically, forming a kind of network (Fig. 4B).
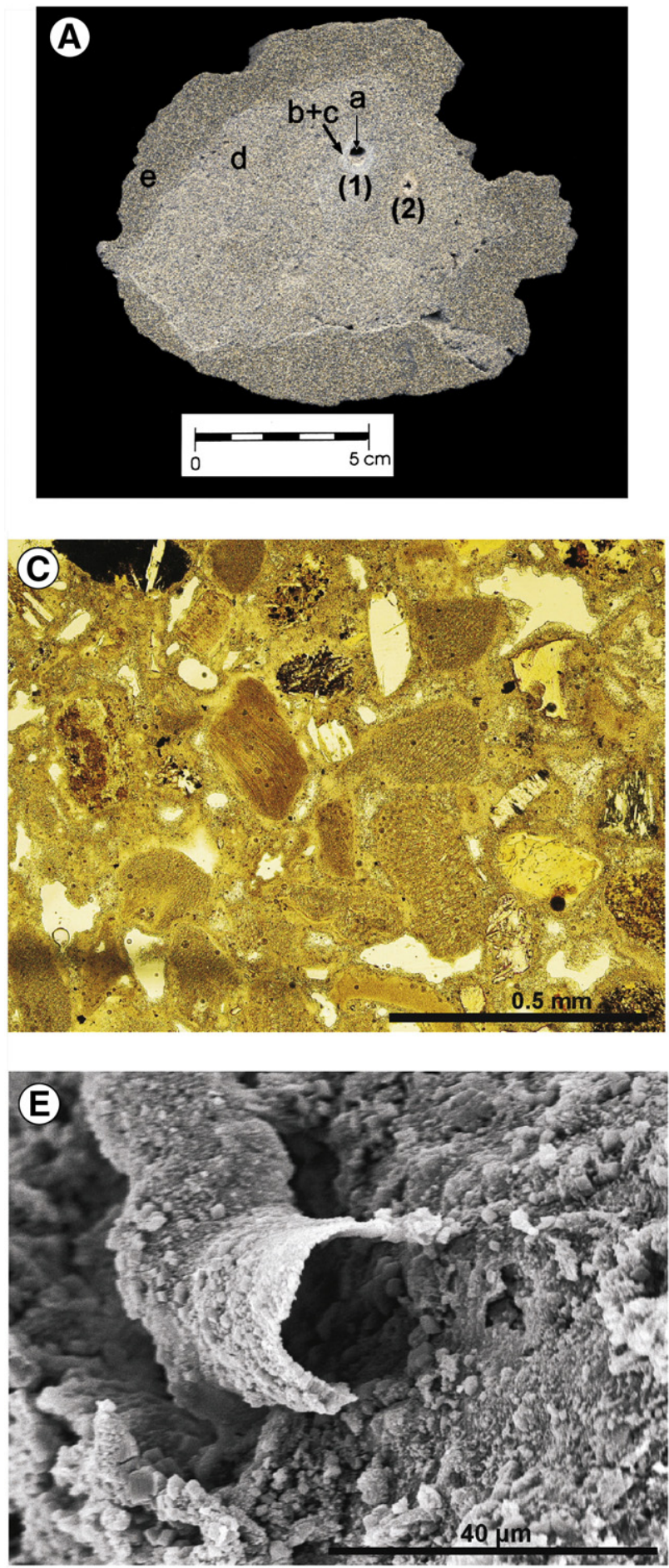

Zone (b) is formed by white porous carbonate which shows an alveolar septal structure (Fig. 6B). Zone (b) is very porous. The carbonate is composed of very fine micrite crystals with cylindrical pores coated by micrite, which includes remains of biofilms and some calcified filaments of about $200 \mu \mathrm{m}$ in length and $5 \mu \mathrm{m}$ in diameter are observed (Fig. 6C and D). Zone (c) is composed of dense, laminated to massive micrite (Fig. $6 \mathrm{E}$ ) and appears between the carbonate with the alveolar septal structure and the external wall, but is absent in many
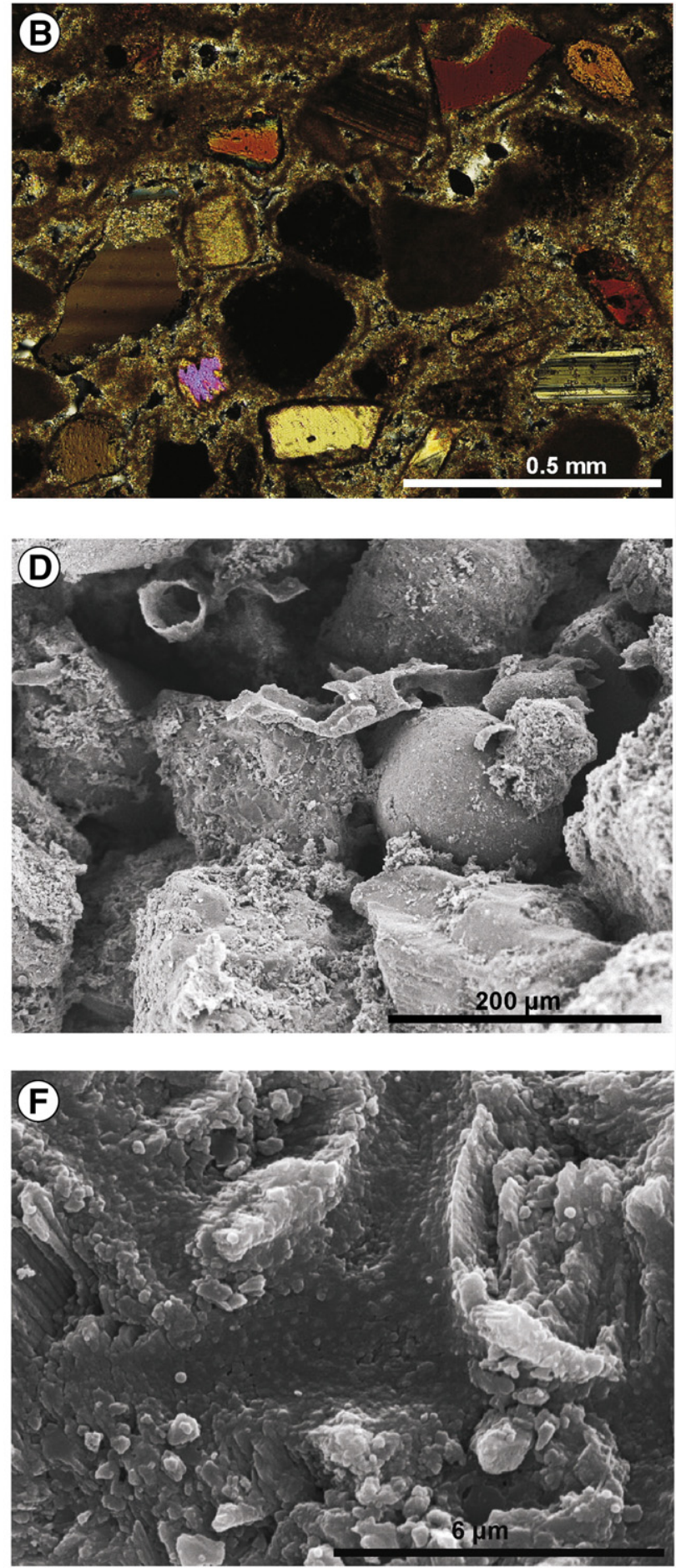

Fig. 7. A. Polished hand sample of a megarhizolith showing the different Zones (see legend of Fig. 6 A for explanation). Two thin roots ( 1 and 2 ) probably account for the formation of this specimen. Note the diameter of the thin roots in comparison to the overall diameter of the megarhizolith. B. View of the cemented sand forming the external part of the megarhizolith; the grains show thin coatings of micrite that lie either directly on the sand grains or on previous cement. C. The micritic +cement coating is stained. D. SEM image of calcified tubes formed by micrite-sized crystals. Vadose cements are also visible. E. Detailed view of the calcified tubes. F. Organic films on the sand grains; some micrite-sized crystals are growing on them. 
specimens. The laminae are very irregular and contain very few sand grains.

The external wall is formed by Zones (d) (internal) and (e) (external). Zone (d) is from well indurated to loose and is composed of light-coloured aeolian sands and micrite-coated sand grains with whiter areas between them (Fig. 7A). The micrite coatings lie directly on the grains or are included between different cement laminae (Fig. 7B). In some cases the micrite coatings show orange staining, probably caused by organic matter (Fig. 7C). The coatings consist of micritic tubes about $30 \mu \mathrm{m}$ in diameter and more than $200 \mu \mathrm{m}$ in length (Fig. 7D). Micrite crystals are present in the empty hollows of the tubes (Fig. 7E). Only exceptionally organic films are seen coating the grains (Fig. 7F). Zone (e) is more cemented than Zone (d). It is composed of darker of aeolian sands with incipient carbonate cements (Fig. 8A-C), probably of aragonite. The crystals are about $20 \mu \mathrm{m}$ long and about $3 \mu \mathrm{m}$ wide. In some cases they totally coat the sand grains (Fig. 8D-F) while in others the coating is irregular. There is usually more than one phase of cementation. The micritic coatings/cements sequence varies within the different zones. Close to the centre (Zone d) the micritic coatings are in contact with the grains and the cements
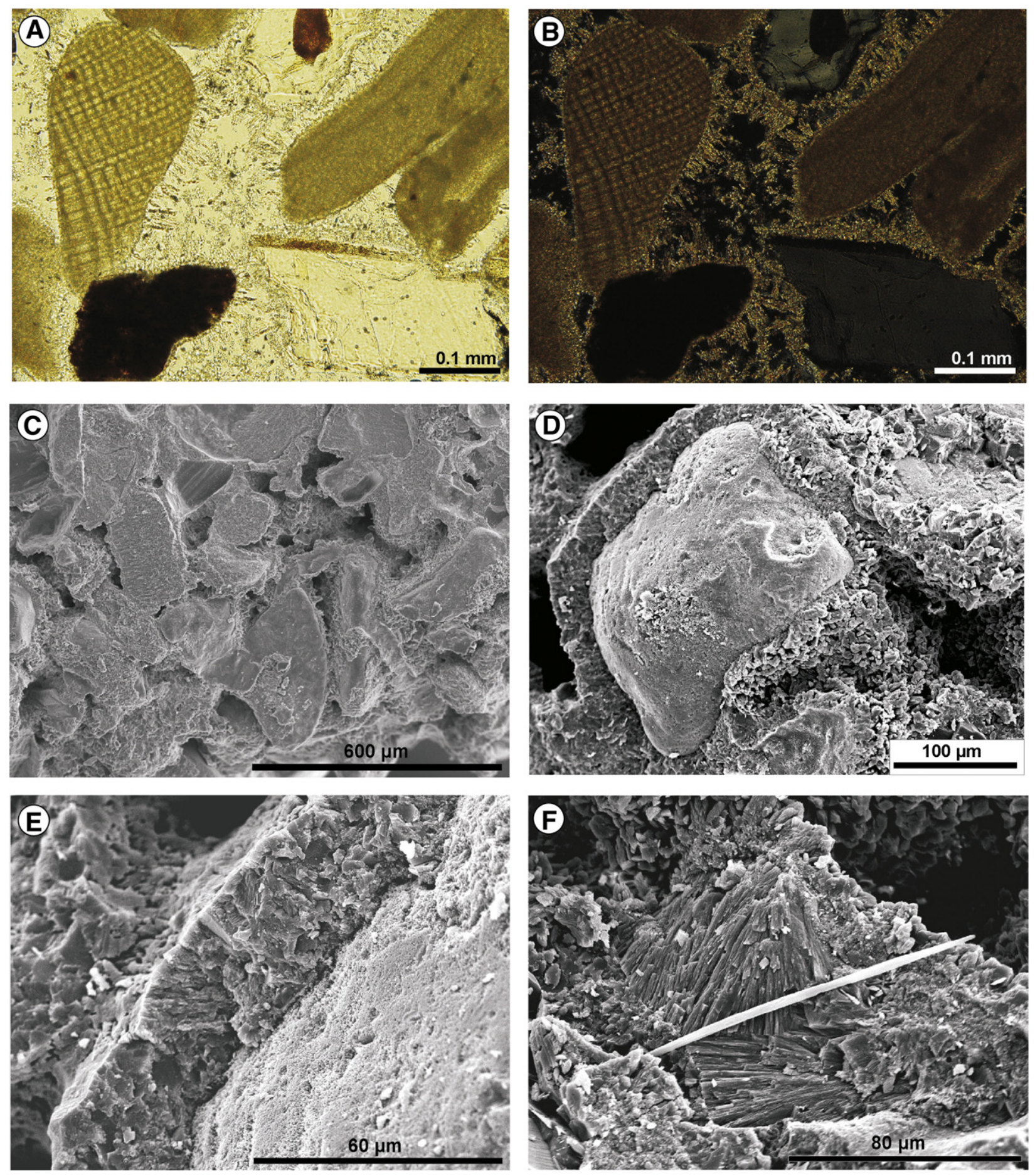

Fig. 8. A. Microphotographs of the cemented sands of Zone (e). B Same image with polarised light. The aragonite crystals lie perpendicularly to the surface of the grains. The rim of cements is not continuous. C. SEM image of the cemented sand of Zone (e). A meniscus between grains is common. D. SEM image of a quartz grain, the surface of which is completely coated by cement. E. Detailed view of D. F. SEM image of aggregates of long crystals arranged in fans, probably of aragonite. 
lie on the micrite-however, in the outermost zones (Zone e) the micrite envelopes tend to be located on the cements.

\section{Discussion}

\subsection{Origin and preservation of structures}

The internal features of the column structures at Tufia, such as the concentric cylinders (Figs. 7 and 8A), the systems of radiating structures (Fig. 5D), and the absence of vertical partitioning (i.e., chambers, menisci), are more compatible with root traces than any structure of animal origin. In addition, most of their external characteristics are more likely related to their exposure to wind after exhumation (see below) than with their origin. The analysis of the internal morphology of these structures reveals that they may have originated through the interaction of root-induced organic and inorganic processes (Calvet et al., 1975, Klappa, 1980). Klappa (1980) defined five types of rhizolith: root moulds, root casts, root tubules, rhizocretions (sensu stricto) and root petrifactions. Rhizocretions are the pedodiagenetic accumulations of mineral matter around roots. Most of the structures found at Tufia can be considered rhizocretions, but there are also moulds, casts and tubules; the term rhizoliths is therefore preferred, or 'megarhizoliths' (McNamara, 1995), due to their size.

The formation of rhizoliths has been widely discussed, especially when these have developed in loose aeolian sediments in which the rooting of plants causes a mechanical effect that moves the grains. This results in a denser grain packing surrounding the root system; in these areas the porosity is lower and the same amount of carbonate cement produces more lithification around the root than in the dunes (Calvet et al., 1975). Further, exuded organic acids assist in the acquisition of mineral nutrients. This strategy of rhizosphere acidification is evident in plants that grow in carbonate-rich, alkaline soils (Marschner, 1995), and is favoured by calcification of the roots (McConnaughey and Whelan, 1997). In addition, in the vicinity of the root system the humidity is retained during longer periods, which favours the development of microorganisms (McLaren, 1995). Microbial activity and acid secretion by the root leads to the appearance of carbonic acid that can dissolve some of the carbonate grain of the dune. The rhizosphere constitutes an unstable chemical microenvironment in which small changes in $\mathrm{pH}$, temperature, soil solution concentration and evapotranspiration cause either precipitation or dissolution processes around the root. The consequence of greater precipitation is a more significant cementation around the root due to the lower porosity in this region (Calvet et al., 1975).

The distribution of the macro- and microfabrics in the Tufia megarhizoliths suggests that their growth is centripetal, as commonly proposed (Calvet et al., 1975; Klappa, 1980). The proposed stages are the following:

1. The most external zone (e) (Figs. 6A and 7A), arises in the area of least influence of the root organic acids and microorganisms. The precipitation of carbonate is mostly related to the migration of calcium and bicarbonate to the outermost and least acidic parts of the rhizosphere. Evaporation could cause rapid oversaturation, allowing the formation of the discontinuous fibrous cements on the sand grains.

2. At the same time (or later on), the microbial association of the rhizosphere induces the precipitation of carbonate on different types of fungal filament and other organic structures, such as root hairs, to form micrite coatings on the grains, as described for the aeolianites of Mallorca (Calvet et al., 1975) and in calcretes (Kahle, 1977; Phillips and Self, 1987). Micrite envelopes are responsible for the whiter parts of the megarhizoliths (Zone [d]), and probably formed in the volume occupied by the root hairs and fungal filaments. These micritic envelopes may or may not reach the outer external zone (e). In some cases, the lack of cements and micritic coatings in Zone (d) would not allow the lithification of the sand; Zone (d) could therefore be lost due to wind erosion.

3. In the last stages, the processes include $A$ ): the infilling of the space occupied by the root (Zones $b+c)$ due to the precipitation of both laminated to massive micrite and white carbonate, some of which has alveolar septal structure (Fig. 7A). This microfabric is formed by the precipitation of carbonate around fungal filaments (Wright, 1986). This happens during the life of the root or when it is slowly decaying. $\mathrm{B}$ ) When the decay of the root is faster, the precipitation of the carbonate in the central area may not be possible; a hollow is thus preserved, represented by Zones $(a+b+c)$. Many intermediate situations between $A$ and $B$ occur, such as the preservation of small calcified root hairs, or just the alveolar carbonate without the laminated micrite or vice versa. All these situations probably arise through the interplay between the activity of microorganisms in the rhizosphere and the decay and decomposition of the root.

The Cyperaceae (Cyperus capitatus, Vandelle) presently living at Tufia are producing concretions around their roots, although their size is not comparable with those of the megarhizoliths. However, they should be considered possible producers of such structures since megarhizolith micro- and macrofabrics indicate that the size of the original root (Zones [a] to [b] in Figs. 6A and 7A) may be very small in relation to the overall diameter of the megarhizolith.

Most of the external characteristics of the megarhizoliths described herein result from, or are enhanced by wind action since they are orientated according with the prevailing winds. Wind removal of the rock matrix resulted in the present exhumation of the megarhizoliths, which are now exposed as free-standing structures partly covered by sand dunes. The surface texture of the external wall composed of short cylinders, which in some cases forms boxworks, is interpreted as the result of the wind's enhancement of second order rhizocretions (compare with Klappa, 1980, Fig. 3E). Also enhanced by the wind are the two rings of matrix surrounding the specimen in Fig. 5E. These are interpreted as the remains of the original bedding of the deposit, probably ancient soil surfaces. Other important characters of the megarhizoliths are also related to the wind direction. Elliptical sections and the eccentricity of the central shaft produced by the root are not found in megarhizoliths included in the rock matrix. They are shown only in the weathered ones, possibly in those more exposed to the present wind which are wind-orientated. The weathering is stronger on the windward side of the rhizolith, leading to a reduction in the thickness of its wall and an artificial "migration" of the central cavity to the windward side of the structure. The flanks are also more eroded than the leeward face, thus producing the elliptical crosssection. This leeward face is the most protected from wind action, resulting in the formation of a relatively long tail in some specimens. In some cases, the texture of the tail and the remains of the rock matrix beside it are composed of horizontal, parallel cylinders. These can be also interpreted as wind shadows produced behind a more consolidated piece of matrix. Fig. 5G shows an example of this from the Miocene Pinturas Formation (Argentina), in which discrete concretions produced more or less cylindrical wind shadow structures.

\subsection{A comparison of the megarhizoliths with other biogenic structures}

In young rocks such as those analysed in the present study, in which many macro- and micromorphological characters are well preserved, confusion between megarhizoliths and other biogenic structures is unlikely to be a problem. However, in older rocks and/or with poorly preserved material, cylinders of similar diameter could be confused with other kinds of biogenic structure, such as tree stump casts or animal traces. This could result in misleading palaeoenvironmental interpretations. It is therefore necessary to emphasize the relatively large diameter (up to $31.5 \mathrm{~cm}$ ) of rhizoliths-up to 30 times the diameter of the root (which may have been less than $1 \mathrm{~cm}$ in 
diameter) that originated them. If this occurs in older rocks in which no diagnostic characters are preserved, the possible interpretation of these structures as tree stump casts would lead to the erroneous conclusion of a more humid, forested landscape, however we are dealing with thin roots developing in an arid landscape.

Depending on the subsequent depositional, weathering, and taphonomic history of aeolian deposits, free-standing structures such as these can erroneously taken to be epigeous trace fossils. Recently, Bordy et al. (2004) described sandstone pillars from aeolian settings of the Tuli Basin of South Africa, attributing them to "advanced Jurassic termite nests". This interpretation was disputed by Genise et al. (2005) who referred to Australian megarhizoliths as comparable structures. Previously, Bordy and Catuneanu (2002) had ruled out the Tuli pillars as root traces due to the lack of downward ramification, tapering diameter, or any radiation from a central axis, i.e., by applying the classical definition of rhizocretions. Interestingly some of the external and internal characteristics of the Tuli pillars match some of those described in the present work. For example, the external features are represented by: (1) free-standing vertical columns composed of sand identical to the rock matrix; (2) the uppermost portions are generally missing and the lower parts are only rarely exposed; (3) the crosssection is elliptical, and the pillars are orientated with the wind; and (4) orientated buttresses (tails?) are present. In addition, the internal structure of the Tuli pillars involves two types of sandstone-filled burrows, larger shafts, and empty spaces-resembling the structures described in the present work. These include: (5) one type of burrow with a web-like network, comparable to the network of second order rhizocretions described in the present work; (6) another type of "burrow" that is horizontal, parallel and strongly orientated, like the cylindrical wind shadows documented for the present megarhizoliths; (7) open, straight shafts that generally penetrate the centre of the pillars, just like the Tufia structures; and (8) an empty space (in some specimens) between the central part and the exterior wall, as seen in some of the present megarhizoliths. Genise et al. (2005) indicated that the strong orientation of the structures in the Tuli pillars cannot be explained in terms of termite biology, suggesting that they have their origin in some erosive agent with a defined direction. From aeolian settings in the Jurassic Morrison Formation (USA), Hasiotis (2004, Fig. 23) recorded giant cylindrical structures that resemble megarhizoliths. Regrettably, the description of the trace fossils in that paper is too brief to allow any discussion regarding their origin (Bromley et al., 2007). However, when analysing the origin of this type of structure, Roth et al. (2006) ruled out fulgurite and termite nests because of the lack of any micro- or macromorphological characters. A root origin was also considered problematic given the classical rhizolith morphologies used in comparisons, which as shown herein do not cover the broad morphological range that root traces display.

\subsection{Palaeoenvironmental implications}

This study provides a further example of the common association between rhizoliths and aeolianites; calcretes provide the other setting in which rhizoliths are commonly found. The mobility of carbonate in both such settings is limited because water supplies are reduced, thus carbonate is moved to and fixed in the zones in which water can be retained for longer. In aeolian settings, with very permeable sediments, this mostly occurs in the proximity of the roots. The aragonite composition of some grains, together with capillary-rise processes, provides vadose water rich in calcium and carbonate, contributing to the precipitation of inorganic aragonite cements around grains and to organically induced precipitation by the roots and their rhizosphere. Some water is, however, always needed, and in these arid settings it is very probable that the levels containing the rhizoliths indicate more humid conditions (which would have allowed more intense plant colonisation). This would have favoured incipient soil development and smaller aeolian sedimentation rates in a more stable landscape (Fig. 9). Stable isotope analyses performed in different settings, such as in the loess-palaeosol deposits of Illinois (Wang et al., 2004) or the lake-margin deposits of the Olduvai Gorge (Liutkus et al., 2005), have reflected the seasonal growth of rhizoliths, the results indicating the alternation of relatively wetter and drier periods. Accordingly, it is very probable that the present megarhizoliths, with their large diameters, formed during the relatively wetter periods of an arid but seasonal climate. The plants that formed them were able to penetrate deeper into the aeolian sediments (Fig. 9), probably to get water.

Racemization analyses carried on gastropod shells of Theba genus, from the Tufia aeolianites give ages comprised between $31.2 \pm 6.2$ and $34.3 \pm 8 \mathrm{ky}$ (Mangas et al., in press). This data in the range of those obtained for Mallorca $\left(37,100 \pm 800{ }^{14} \mathrm{C}\right.$ yr to 41,000 cal yr BP) (Clemmensen et al., 2001) and Lanzarote (between 50,000 and

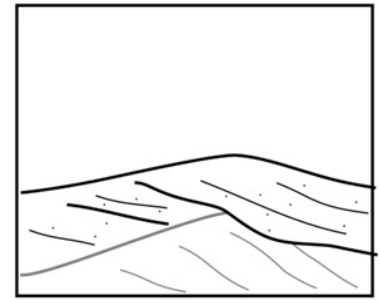

A

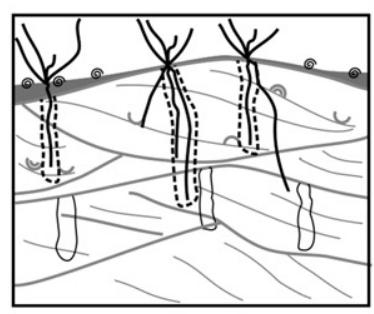

D

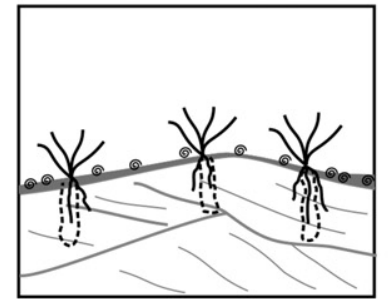

B

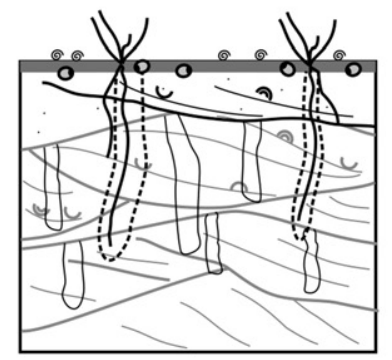

E

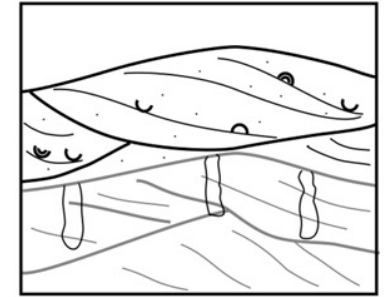

C

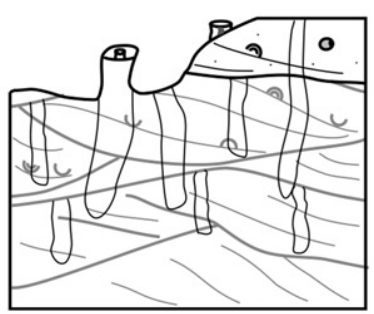

Final aspect

\section{LEGEND}

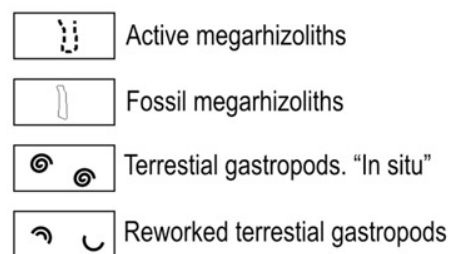

\section{Insect trace fossils}

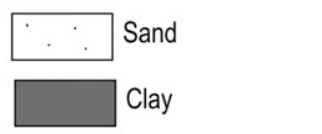

Fig. 9. Sketch showing the different episodes that might account for the formation of the megarhizoliths. Episodes of aeolian sedimentation (A, and C) were followed by episodes of incipient soil formation and the development of roots; these periods (B, D, and E) were favourable to the existence of gastropods and insects. Later erosion and quarry work gave place to the present appearance of the outcrop. 
30,000 yr BP) (Hillaire-Marcel et al., 1995). Both in Mallorca and Lanzarote the aeolianites appear to have formed when the sea level was about $50 \mathrm{~m}$ lower than it is today (Bradley, 1999). The aeolianites of Tufia also could form during a low sea level stage. With respect to the megarhizoliths the dating of some aeolianite beds (Mangas et al., in press), suggests that the formation of each aeolianite bed and their topmost megarhizoliths occurred in periods of the order of a few hundred years, because the overall outcrop will record about 3100 yr. Each sequence of aeolian activity followed by stabilization of the dunes by the roots (or their preserved megarhizoliths) may reflect arid climates (probably close to present conditions) followed by less arid periods during which the vegetation colonised the dunes. Biological, mineralogical and geochemical studies performed in loess, palaeosols and aeolianites from Lanzarote, Fuerteventura and NW Africa (Petit-Maire et al., 1986; Hillaire-Marcel et al., 1995; Rognon and Coudé-Gaussen, 1996; Gasse, 2000) record arid phases followed by humid transitions between 23 and $50 \mathrm{ky}$ BP. The distribution of these aeolianite beds with rhizoliths all along the Canaries, and even in the Mediterranean indicates that there were regional and not local controls on their formation. The alternation of at least five dry/humid episodes has been inferred from the amino acid racemization results obtained in gastropods from the eastern Canary Islands living before the Last Glacial Maximum (23-18 ka BP) (Ortiz et al., 2006). Thus, in arid settings the presence of these structures is a good indicator of the relatively wetter periods.

\section{Conclusions}

1. The Pleistocene Tufia dune field comprises several aeolian beds which at the top show free-standing columnar structures that can reach $31.5 \mathrm{~cm}$ in diameter and over $1 \mathrm{~m}$ in height. Based on their macro- and particularly micromorphological characteristics, these structures are interpreted as megarhizoliths.

2. Micromorphologically, their cross-sections show five concentrically arranged zones. Zone (a) is the most internal; this is porous and represents the original location of the root. Zones (b) $+(\mathrm{c})$ are formed from alveolar and laminated micrite; this would be formed by the activity of the root and its associated rhizosphere microorganisms. Zone (d) consists of sand grains with thin micritic coatings and/or vadose cements; in some cases this is absent due to a low level of cementation. Zone (e) is the outermost and most indurated ring, and consists of sand grains with larger amounts of vadose aragonite cements; this is favoured by the capacity of roots to maintain higher levels of humidity in their vicinity.

3. Macromorphologically, the free-standing megarhizoliths show many features produced or enhanced by the wind after their exhumation, such as their elliptical section, the eccentricity of the central shaft, the surface texture of the external wall (composed of short cylinders forming boxworks), tails or "wind shadows", and the presence of horizontal, parallel cylinders resembling burrows.

4. The diameter of the original root may be 30 times smaller than the diameter of the megarhizolith, showing that these large structures are not necessarily originated by large roots, trunks, or in densely vegetated areas as may be supposed from their size and abundance. These megarhizoliths could also be misinterpreted as epigeous insect nests from which they are distinguishable after the recognition of the macro- and micromorphological features described.

5. The correct interpretation of these structures is critical for obtaining palaeoecological and palaeoclimatic inferences. The relationship between the aeolian sediments and the megarhizoliths indicate that the Tufia dune field was formed under arid conditions when the sea level was much lower than at present. Under these conditions the plants producing the original roots would have colonised the dunes during slightly wetter periods; aeolian deposits lacking plants would represent more arid times. This alternation of arid and less arid stages has been detected in other deposits of the Canary Islands and Mallorca, supporting the proposals made in this work.

\section{Acknowledgements}

This work was funded by project CGL-2005-5953-C02-02 and by CCG07-UCM/AMB-2299 from the Spanish Ministerio de Educación y Ciencia. J.F. Genise was also supported by grant PICT 13286 from the Argentine Agencia Nacional de Promoción Científica y Tecnológica. All SEM studies were performed at the Centro de Microscopía Luis Brú-UCM. A. Martín-Pérez is supported by an I3P grant from CSIC. A. Valdeolmillos is supported by Juan de la Cierva Program (MEC). Adrian Burton is thanked for his revision of the English manuscript. We thank F. Surlyk, D. Loope and an anonymous reviewer their helpful comments.

\section{References}

Bordy, E.M., Catuneanu, O., 2002. Sedimentology and palaeontology of upper Karoo aeolian strata (Early Jurassic) in the Tuli Basin, South Africa. Journal of African Earth Sciences 35, 301-314

Bordy, E.M., Bumby, A.J., Catuneanu, O., Eriksson, P.G., 2004. Advanced early Jurassic termite (Insecta: Isoptera) nests: evidence from the Clarens Formation in the Tuli Basin, Southern Africa. Palaios 19, 68-78.

Bradley, R.S., 1999. Palaeoclimatology: Reconstructing Climates on the Quaternary. Academic Press, San Diego. 613 pp.

Bromley, R.G., Buatois, L.A., Genise, J.F., Labandeira, C.C., Mangano, M.G., Melchor, R.N., Schlirf, M., Uchman, A., 2007. Comments on the paper "Reconnaissance of Upper Jurassic Morrison Formation ichnofossils, Rocky Mountain Region, USA: paleoenvironmental, stratigraphic, and paleoclimatic significance of terrestrial and freshwater ichnocoenoses" by Stephen T. Hasiotis. Sedimentary Geology 200, 141-150.

Calvet, F., Pomar, L., Esteban, M., 1975. Las Rizocreciones del Pleistoceno de Mallorca. Inst. Invest. Geol. Univ. Barcelona 30, 35-60.

Camino, J., 1997. Los espacios naturales protegidos: análisis geográfico de las disfunciones entre potencialidad natural y usos reales. Los ejemplos de Tufia y Arinaga (Gran Canaria, Islas Canarias). Ph.D. Thesis, Universidad de Las Palmas de Gran Canaria, Las Palmas de Gran Canaria, 192 pp.

Carracedo, J.C., Pérez-Torrado, F.J., Ancochea, E., Meco, J., Hernán, F., Cubas, C.R., Casillas, R., Rodríguez Badiola, E., 2002. Cenozoic volcanism: II. The Canary Islands. In: Gibbons, F.A.W., Moreno, T. (Eds.), The Geology of Spain. Geological Society of London, London. 438-472.

Clemmensen, L.B., Lisborg, T., Fornós, J.J., Bromley, G.R., 2001. Cliff-front aeolian and colluvial deposits, Mallorca, Western Mediterranean: a record of climatic and environmental change during the last glacial period. Bulletin of the Geological Society of Denmark 48, 217-232.

CMA, 2005. Normas de conservación del Sitio de Interés Científico de Tufia. Documento informativo. $66 \mathrm{pp}$.

Ekdale, A.A., Bromley, R.G., Pemberton, G., 1984. Ichnology. The use of trace fossils in sedimentology and stratigraphy. Society of Economic Paleontologist and Mineralogists, Short Course, vol. 15, pp. 1-315.

Folk, R.L., Ward, W.C., 1957. Brazos River bar (Texas). A study in the significance of grain size parameters. Journal of Sedimentary Research 27, 3-26.

Gardner, R.A.M., McLaren, S.J., 1993. Progressive vadose diagenesis in late Quaternary aeolianite deposits? Geological Society, London, Spec. Publ., vol. 72, pp. 219-234.

Gasse, F., 2000. Hydrological changes in the African tropics since the Last Glacial Maximum. Quaternary Science Reviews 19, 189-211.

Genise, J.F., Bellosi, E.S., Melchor, R.N., Cosarinsky, M.I., 2005. Comment-Advanced early Jurassic termite (Insecta: Isoptera) nests: evidence from the Clarens Formation in the Tuli Basin, Southern Africa (Bordy et al., 2004). Palaios 20, 303-308.

Guillou, H., Pérez Torrado, F.J., Hansen Machin, A.R., Carracedo, J.C., Gimeno, D., 2004. The Plio-Quaternary volcanic evolution of Gran Canaria based on new K-Ar ages and magnetostratigraphy. Journal of Volcanology and Geothermal Research 135, 221-246.

Hasiotis, S.T 2004. Reconnaissance of Upper Jurassic Morrison Formation ichnofossils, Rocky Mountain Region, USA: paleoenvironmental, stratigraphic, and paleoclimatic significance of terrestrial and freshwater ichnocoenoses. Sedimentary Geology 167, $177-268$.

Hernández, L., Mangas, J., 2004. Caracterización de los materiales sedimentarios aflorantes en el sistema de dunas de Maspalomas (Gran Canaria, Islas Canarias). In: Blanco Chao, R., López Bedoya, J., Pérez Alberti, A. (Eds.), Procesos geomorfológicos y evolución costera. Universidad de Santiago de Compostela, pp. 67-81.

Hillaire-Marcel, C., Ghaleb, B., Gariépy, C., 1995. U-series dating by TIMS technique of land snails from paleosols in the Canary Islands. Quaternary Research 44, 276-282.

ITGE, 1990. Mapa Geológico de España a escala 1:25.000, hoja de Telde (1109-II) y memoria. Ed. ITGE, Madrid. $101 \mathrm{p}$.

Jones, B., Kwok-Choi, N., 1988. The structure and diagenesis of rhizoliths from Cayman Brac, British West Indies. Journal of Sedimentary Research 58, 457-467.

Kahle, C.F., 1977. Origin of subaerial Holocene calcareous crusts: role of algae, fungi and sparmicritisation. Sedimentology 24, 413-435.

Klappa, C.F., 1978. Biolithogenesis of Microcodium: elucidation. Sedimentology 25, 489-522.

Klappa, C.F., 1980. Rhizoliths in terrestrial carbonates: classification, recognition, genesis and significance. Sedimentology 27, 613-629.

Kindler, P., Hearty, P.J., 1995. Pre-Sangamonian eolianites in the Bahamas? New evidence from Eleuthera Island. Marine Geology 127, 73-86.

Kosir, A., 2004. Microcodium revisited: root calcification products of terrestrial plants on carbonate-rich substrates. Journal of Sedimentary Research 74, 845-857. 
Liutkus, C.M., Wright, J.D., Ashley, G.M., Sikes, N.E., 2005. Paleoenvironmental interpretation of lake-margin deposits using $\delta^{13} \mathrm{C}$ and $\delta^{18} \mathrm{O}$ results from early Pleistocene carbonate rhizoliths, Olduvai Gorge, Tanzania. Geology 33, 377-380.

Loope, D.B., 1988. Rhizoliths in ancient eolianites. Sedimentary Geology 56 (1-4), 301-314

Mangas, J., Hernández-Calvento, L., Pérez-Chacón, E., Menéndez, I., Gauraz, A.L., Hernández-Cordero, A., 2007. The Outcrop of the Underlying Substratum of the Maspalomas Dune Field (Gran Canaria, Canary Islands): a Sign of a Sedimentary Deficit, Simposio Internacional de Ciencias del Mar, ISMS07, Valencia, p. 55.

Mangas, J.: Menéndez, I., Ortiz, J.E. Torres, T., in press. Eolianitas costeras del Pleistoceno superior en el "Sitio de Interés Científico de Tufia" (Gran Canaria): sedimentología, petrografía y aminocronología. Geotemas 10 .

Marschner, H., 1995. Mineral Nutrition in Higher Plants, 2nd Edition. Academic Press, Amsterdam. 889 pp.

McConnaughey, T.A., Whelan, J.F., 1997. Calcification generates protons for nutrient and bicarbonate uptake. Earth-Science Reviews 42, 95-117.

McLaren, S.J., 1995. Early carbonate diagenetic fabrics in the rhizosphere of late Pleistocene aeolian sediments. Journal Geological Society 152, 173-181.

McNamara, K., 1995. Pinnacles. Western Australia Museum Press, Perth. 27 pp.

Mount, J.F., Cohen, A.S., 1984. Petrology and geochemistry of rhizoliths from PlioPleistocene fluvial and marginal lacustrine deposits, east Lake Turkana, Kenya. Journal of Sedimentary Petrology 54, 263-275.

Murray, R.G., Anthony, J.M., Kathelee, A.C., 2004. Compound trace fossils formed by plant and animal interactions: Quaternary of northern New Zealand and Sapelo Island, Georgia (USA). Fossils and Strata 51, 88-105.
Ortiz, J.E., Torres, T., Yanes, Y., Castillo, C., De La Nuez, J., Ibáñez, M., Alonso, M.R., 2006 Climatic cycles inferred from the aminostratigraphy and aminochronology of Quaternary dunes and palaeosols from the eastern islands of the Canary Archipelago. Journal of Quaternary Science 21, 287-306.

Petit-Maire, N., Delibrias, G., Meco, J., Pomel, S., Rosso, J.C., 1986. Paléoclimatologie de Canaries orientales (Fuerteventura). Comptes Rendus de l'Academie Sciences, Paris 303, $1241-1246$

Phillips, S.E., Self, P.G., 1987. Morphology, crystallography and origin of needle fiber calcite in quaternary pedogenic calcretes of South Australia. Australian Journal of Soil Research 25, 429-444.

Retallack, G.J., 2001. Soils of the Past: an Introduction to Paleopedology, 2nd ed. Blackwell Science, Boston, $404 \mathrm{pp}$.

Rognon, P., Coudé-Gaussen, G., 1996. Paleoclimates of Northwest Africa $\left(28^{\circ}-35^{\circ} \mathrm{N}\right)$ about 18,000 yr B.P. based on continental aeolian deposits. Quaternary Research 46 , $118-126$

Roth, A.A., Hornbacher, D., Zoutewelle, T., 2006. Complex concretions in the Jurassic Morrison Formation. Geological Society of America 38, 7 Abstracts with Programs. Wang, H., Ambrose, S.H., Fouke, B.W., 2004. Evidence of long-term seasonal climate forcing in rhizolith isotopes during the last glaciation. Geophysical Research Letters 31.

Wright, V.P., 1986. The role of fungal biomineralization in the formation of Early Carboniferous soil fabrics. Sedimentology 33, 831-838 